*ak RMIS View/Frint Document Cover Sheet tow

This document was retrieved from the Documentation and Records Manaqement (DRM) ISEARCH System. It is intended for Information only and may not be the most recent or updated version. Contact a Document Service Center (see Hanford Info for locations) if you need additional retrieval information.

Accession \#: D196012375

Document \#: SD-SNF-HC-010

Title/Desc:

HAZARD CATEGORIZATION OF 105KE BASIN DEBRIS REMOVAL PROJECT

Pages: 11 
3. From: IOrghuth Oresuretion)

$\mathrm{K}$ Basins Stanclards and

K Basins Projects

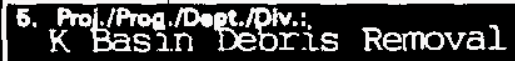

8. Originutor Romanke:

Firr Relecise

1. $\operatorname{EDT}$

Pere 1 of 701976

4. Ralered EDT Mo.:

140734

7. Arehree order No.:

D. Equip./Component No:

10. Syotom/Bda.fFenlity:

105KE

12. Mor Anse Dwn No:

13. Permithermin Appollection No.:

14. Paquired Faeponce Dota:

\begin{tabular}{|c|c|c|c|c|c|c|c|c|}
\hline 15. & & DATA TR & NSMTTE & & $(\mathbf{F})$ & (3) & (H) & (i) \\
\hline $\begin{array}{l}(A) \\
\text { hem } \\
\text { No. }\end{array}$ & (B) Documant/Drawing No. & $\begin{array}{l}\text { (C) Sheort } \\
\text { No. }\end{array}$ & $\begin{array}{l}\text { (D) Rov. } \\
\text { No. }\end{array}$ & $\begin{array}{c}\text { (E) This or Daiceription of Deta Trenemitted } \\
\text { of }\end{array}$ & $\begin{array}{l}\text { Apprevd } \\
\text { Deslo } \\
\text { netor }\end{array}$ & $\begin{array}{l}\text { Aosioen } \\
\text { for Trant- } \\
\text { mittel }\end{array}$ & $\begin{array}{l}\text { Oriph } \\
\text { nater } \\
\text { Dispo- } \\
\text { rtion }\end{array}$ & 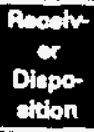 \\
\hline 1 & WHC-SD-SNF-HC-010 & $=$ & 0 & $\begin{array}{l}\text { Hazard Categorization } 105- \\
\mathrm{K} \mathrm{E} \text { Basin Removal Project }\end{array}$ & $S$ & & & \\
\hline & & & & Denkis & & & & \\
\hline & & & & & & & & \\
\hline & & & & & & & & \\
\hline & & & & & & & & \\
\hline & & & & & & & & \\
\hline & & & & & & & & \\
\hline & & & & & & & & \\
\hline
\end{tabular}

16.

Approval Designator if

E. S, O, D OAN/A SSea WHC-CM-3.5.

Sac. 12.7

\begin{tabular}{|c|c|}
\hline \multicolumn{2}{|c|}{ Resean for Trenemittal (G) } \\
\hline $\begin{array}{l}\text { 1. Approvel } \\
\text { 2. Aplones } \\
\text { 3. Intornotion }\end{array}$ & 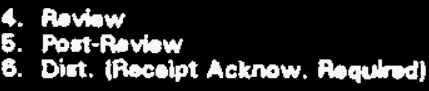 \\
\hline
\end{tabular}

SIGNATURE/OLSTREUTION

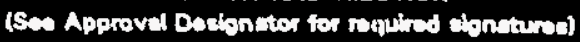

\begin{tabular}{|c|c|c|c|}
\hline (c) & (H) & 17. & 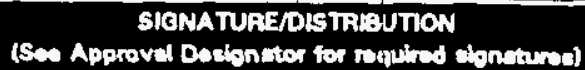 \\
\hline
\end{tabular}

(K) Signature

(L) Dote (M) MSIN (4) Nemo

1. Approved

2. Approwd w/eomment

Dipepproved w/oom
Diapochion (H) A (i)

4. Roviswad nolocinment

5. Roviawed whootinimit

e. Reoelpt coknowledged

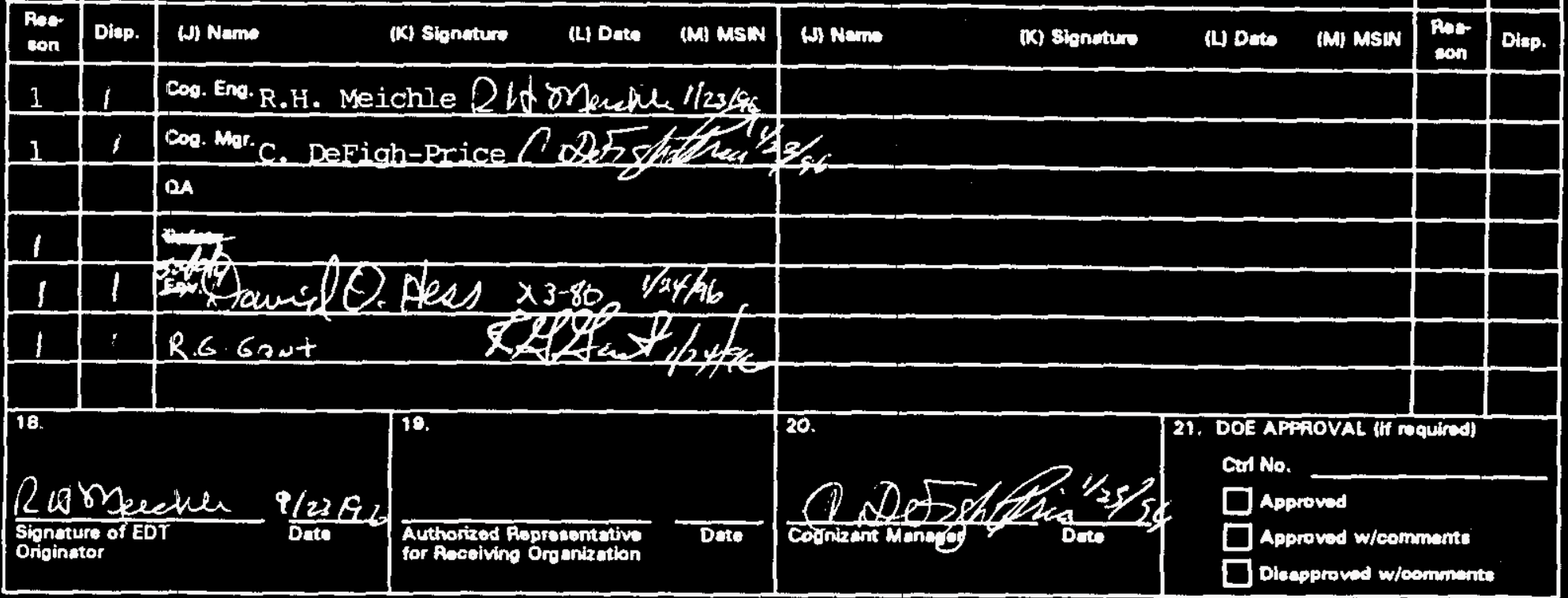




\section{Hazard Categorization of 105-KE Basin Debris Removal Project}

RH Meichle

Westinghouse Hanford Company, Richland, WA 99352

U.S. Department of Energy Contract DE-AC06-87RL10930

EDT/ECN: 701976

Org Code: $2 A 100$

UC: 500

B\&R Code: EW3135040

Charge Code: $1 \mathrm{~d} 006$

Total Pages: 8

Key Words: Hazard Categorization, Debris Removal. Canister Cleaning. 105KE Basin

Abstract: This supporting document provides the hazard categorization for 105-KE Basin Debris Removal Project activities planned in the $K$ east Basin. Al1 activities are categorized as less than Hazard Category 3.

TRADEMARK DISCLAIMER. Reference herein to any specific commercial product, process, or service by trade name. trademark. manufacturer. or otherwise, does not necessarily constitute or imply its endorsement, recommendation, or favoring by the United States Government or any agency thereof or its contractors or subcontractors.

Printed in the United States of America. To obtain copies of this document, contact: WHC/BCS Document Control Services, P.O. Box 1970, Mailstop H6-08, Richland WA 99352. Phone (509) 372-2420; Fax (509) 376-4989.

venis Bradon $\frac{1125196}{\text { Date }}$

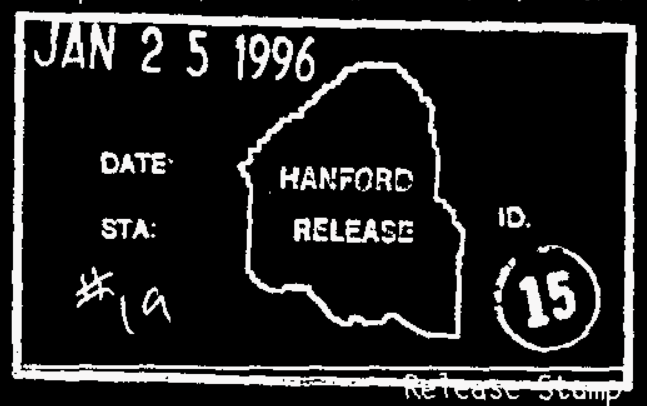

\section{Approved for Public Release}




\section{HAZARD CATEgORIZATION OF 105-KE BASIN DEBRIS REMOVAL PROJECT}

\subsection{PURPOSE AND SCOPE}

The purpose of this document is to provide a hazard categorization of the activities associated with the KE Basin Debris Removal Project. Hazard Categorization utilizes the method provided by DOE Standard DOE-STD-1027(Reference 1). The Project is to remove tools and equipment, and miscellaneous articles canisters, old fuel handling removal of spent fuel, neutron activated incidental quantities is to be the basin is addressed. The made by the Project. However, sludge moving in categorization is based is contains Description upon which this

\subsection{SUMMARY}

All activities associated with the KE Basin Debris Removal are less than
Hazard Category 3 . No significant nonradioactive risks were identified.

\subsection{DESCRIPTION OF SIGNIFICANT ACTIVITIES}

The scope of the debris removal activities which impact hazard categorization
are:

- $\quad$ Pumping of sludge.

- Removal of debris from KE Basin access/egress paths.

- Eventual removal of all debris from basin.

- Sizing and Packaging of debris for disposition.

- Shipment of debris for disposal.

New system/equipment of importance are:

- High Pressure Water Jet System. A high pressure (up to 15,000 psi at nozzle with flow rates up to $15 \mathrm{gpm}$ ) water jet system to remove most of
surface oxidation and contaminations.

- Drip Dry/Bag Out Enclosures. An enclosure with High Efficiency Particulate Filter (HEPA) with drying racks and bag-out port to 1 imit airborne contamination of building atmosphere.

- Vacuum System to Relocate Sludge. with use of vacuum pumps.

- Water Clarity Equipment (filters). 
WHC-SD-SNF-HC-010 Revo

Page 2 of 7

\subsection{HAZARD CATEGORIZATION}

The methodology of DOE Standard DOE-STD-1027-92 (Reference 1) is utilized for this hazard categorization. This methodology establishes the hazard categorization based upon the potential airborne release from the inventory of radioactive materials including form as processed.

The form of material when handled under water is considered to include the effect of the water on the release path for the radioactive material. For such handling, the amount of radioactive material being handled or that can be impacted by the handling is compared the Threshold values of reference 1 which are multiplied by the conservatively assumed decontamination factor (DF) for water of $10^{+4}$ (Reference 3 ). For radioactive material out of the bas in the Threshold value of reference 2 are used unaltered. Source terms were taken
from Reference 4 .

\subsection{Underwater Activities}

The maximum amount of fuel or sludge that the underwater activities present a hazard to is used to compare to the Categorization thresholds. These thresholds have been increased by the DF of $10^{+4}$. The amount of radioactive material that can be at risk and still be less than Category 3 must be less than the amount of fuel in 18.5 canisters $(13,4001 \mathrm{bs})$ per Table 1 , or less than 5.92 E+05 pounds of sludge (Wease 1 pit) per Table 2. Table 3 shows the amount of KE Sand Filter Backwash Pit sludge for Category 3 threshold as 169 1bs. The amount of basin water to exceed Category 3 threshold values is 225,000 gallons per Table 4.

A review of Reference 2 indicates that all activities will involve and/or impact less than threshold quantities of radioactive material as discussed
below. - Impact on stored fuel - No large or heavy loads that could impact 18
canisters of fuel are to be used.

- Sludge pumping - The amount of sludge pumped at any one time will be less than the $5.95 E+05$ pounds and there is not a large enough energy source to produce significant airborne radioactive material releases. Used filters will be stored underwater in canisters for later removal and the release potential is less than prior to processing. Sludge pumping is an activity that has been performed several times in the past.

- High pressure water jet operations - These operations are performed on single components under water and are localized so the amount of fuel and sludge that can be affected is small. Even if a canister loaded with fuel mistakenly selected rather than an empty canister only one canister is affected. The debris will only have surface contamination so that large quantities of radioactive material will not be present when cleaning and the maximum amount of radioactive material will be bounded by the amount in one canister. 
- The High pressure water jet or water clarity equipment leaks - Such equipment would have to run for 24 hours at $150 \mathrm{gpm}$ to remove 225,000 gallons from the pool. Since activities are only performed when the basin is manned this is judged to be an incredible scenario.

- Water clarity filter media - Spent filters will be stored underwater in canisters for later removal. The amount of radioactive material in such canisters will be less than for canisters with fuel. At no time will even 18 canisters with filters have the potential for release. Therefore this activity does not lead to inventories in excess of Category 3 threshold with water DF.

\subsection{Debris Removal from Pool}

The amount of material considered that presents a hazard is based on anticipated upper bounds of residual radioactive material assuming nominal operation of cleaning, drying, and inspection process. Therefore, removal of canisters or other debris with fuel elements or pieces of fuel or even visible quantities of radioactive material or sludge is not considered for the purposes of hazard categorization of the activity. Removal from the pool of a canister containing a fuel assembly was addressed by the Preliminary Hazard Assessment (Reference 6) and was identified as an extremely unlikely event and shown to have acceptable public and onsite dose consequences by the safety analysis. Evaluation of the storage boxes will be based on the conservative assumption that the inventory is equal to the threshold for TRU (100 nanocuries per gram). The Category 3 threshold quantities of radioactive material in various forms out of the pool is 1.3 pounds of uranium metal, 1.5 pounds of uranium oxide, 59.2 pounds of weasel pit sludge, or 169 pounds of sandfilter backwash pit sludge.

- Lifting of debris out of the pool - Uranium metal or oxide by themselves are not expected to be the form of material that would be a contaminant on the cansisters or debris and, if it were, the cleaning process would be effective in removing the bulk of such a contaminant such that Cat 3 threshold values would not be exceed by a single removal action. Contaminants are assumed to be similar to sludge and 59.2 pounds would be noticeable, and in fact $\mathrm{Kg}$ quantities would not be expected to be present after cleaning. Therefore, single canister removal would not result in removal from the bas in of a Category 3 inventory of radioactive material.

- Debris removal from pool and placement in burial boxes - Reference 1 estimates that burial boxes will contain 18 empty canisters. Based on a weight of approximately 31.25 lbs per canister the TRU contamination would have to be 20 times over the TRU limit of 100 nanocuries per gram to exceed the Category 3 threshold (See Table 5). This provides sufficient margin to consider the radioactive material inventory of a box to be less than Category 3 . This also allows for storage of several boxes subject to a single release event. 
WHC-SD-SNF-HC-010 Rer O

Page 4 of 7

- Drip Dry/Bag Out Enclosures HEPA - An enclosure with High Efficiency Particulate Filter (HEPA) with drying racks and bag-out port to limit airborne contamination of building atmosphere will collect contamination. However, only a fraction of the radioactive material inventory that is removed from the pool will become airborne and be adsorbed by the filter or on the surface of the enclosure. Assuming that the airborne release that is absorbed by the filter is uranium oxide, and assuming that the filter media absorbs the Category 3 threshold amount of 1.5 pounds, the total amount of uranium oxide removed from the pool would have to have been 1500 pounds. This calculation used the $10^{-3}$ fraction from DOE-STD-1027-92 for solid/powders/liquids. Since the bulk of the material removed from the pool is assumed to be sludge, the sludge equivalent of 1500 pounds of oxide would be 59,200 pounds. This is considered incredible since this amount of sludge would essentially be equal to the weight of the 1800 canisters being removed. Therefore the filter loading will never exceed Category 3 threshold amounts.

\subsection{Nonradioactive Hazards}

The major nonradioactive hazard is from the high pressure water. Implementation of Water Jet. Association recommended practices (Reference 5) provides adequate control of this hazard.

\subsection{REFERENCES}

1. DOE-STD-1027-92, "Hazard Categorization and Accident Analys is Techniques for Compliance With DOE Order 5480.23, Nuclear Safety Analys is Reports", December 1992.

2. WHC-SD-SNF-SP-003, Rev. 0, "Process Description K Bas in Debris Remova]", J. B. Crysta1, August 9,1995.

3. WHC-SD-SNF-SARR-001, Rev 0, "Review of the Consequences of Uranium Hydride Formation in $\mathrm{N}$-Reactor Fuel Elements Stored in the $\mathrm{K}$ Basins," Weber, J. W., 1994

4. WHC-SD-SNF-RA-001, Rev. 0, "K Basin Safety Analysis," Porten, D. R., and R. D. Crowe, 1994.

5. "Recommended Practices for the Use of Manually Operated High Pressure Water Jetting Equipment" prepared by Water Jet Technology Association, 1994.

6. WHC-SD-SNF-PHA-001, Rev. 0, Prel iminary Hazards Analys is of $K$ Basins Fuel Encapsulation and Storage, Strickland, G. C., 1994. 
WHC-SD-SNF-HC-010RejO

Page 5 of 7

\begin{tabular}{|c|c|c|c|c|c|}
\hline \multicolumn{6}{|c|}{$\begin{array}{r}\text { TABLE } 1 \\
\text { CATEGORY } 3 \text { THRESHOLD QUANTITIES OF URANIUH AND }\end{array}$} \\
\hline \multirow[t]{2}{*}{$\begin{array}{l}\text { RADIONUCLIDE i } \\
\text { IN URANIUH }\end{array}$} & $\begin{array}{l}\text { CURIES/MTU } \\
\text { URAKIUM }\end{array}$ & $\begin{array}{c}\text { CAT } 3 \\
\text { THRESHOLD } \\
\text { Ci }\end{array}$ & $\begin{array}{c}\text { CAT } 3 \\
\text { THRESHOLO } \\
\text { WITH WATER DF } \\
\text { of } 10 E+04 \\
\text { Ci }\end{array}$ & $B(i) / D(i)$ & $B(i) / C(i)$ \\
\hline & $B(i)$ & $c(i)$ & $D(i)$ & & \\
\hline$Y-90^{*}$ & $5.80 E+03$ & $2.10 E+02$ & 2. $10 E+06$ & $2.76 E-03$ & $2.76 E+01$ \\
\hline Sr-90 & $5.805+03$ & $1.60 E+01$ & $1.60 E+05$ & $3.63 E-02$ & $3.63 E+02$ \\
\hline Ru- 106 & $5.20 E+01$ & $1.00 \mathrm{E}+02$ & $1.00 E+06$ & $5.20 E-05$ & $5.20 E-01$ \\
\hline $5 b-125 *$ & $1.20 \mathrm{E}+02$ & $2.10 E+02$ & $2.105+06$ & $5.71 E \cdot 05$ & 5.71E-01 \\
\hline $\mathrm{Te}-125 \mathrm{H}^{\star}$ & $3.00 \mathrm{E}+01$ & $2.10 \mathrm{E}+02$ & $2.10 \mathrm{E}+06$ & $1.43 E-05$ & $1.43 E-01$ \\
\hline $\mathrm{Pr}-1444^{*}$ & $3.30 E-01$ & $2.10 \mathrm{E}+02$ & $2.10 \mathrm{E}+06$ & $1.57 \mathrm{E}-07$ & $1.57 \mathrm{E}-03$ \\
\hline $\operatorname{Pr}-144 *$ & $2.80 \mathrm{E}+01$ & $2.10 \mathrm{E}+02$ & $2.105+06$ & $1.33 \mathrm{E}-05$ & $1.33 \mathrm{E}-01$ \\
\hline $\mathrm{Ce}-144$ & $2.80 \mathrm{E}+01$ & $1.00 \mathrm{E}+02$ & $1.00 \mathrm{E}+06$ & $2.80 \mathrm{E}-05$ & $2.80 E-01$ \\
\hline Cs-134 & $1.30 \mathrm{E}+02$ & 4.20E+01 & $4.20 E+05$ & $3.10 \mathrm{E}-04$ & $3.10 E+00$ \\
\hline Cs. 137 & $7.30 \mathrm{E}+03$ & $6.00 E+01$ & $6.00 E+05$ & $1.22 E-02$ & $1.226+02$ \\
\hline $\mathrm{Pm}-147$ & $2.00 E+03$ & $1.00 E+03$ & $1.00 \mathrm{E}+07$ & $2.00 E-04$ & $2.00 \mathrm{E}+00$ \\
\hline$E u-154$ & $8.80 E+01$ & $2.00 E+02$ & $2.00 E+06$ & $4.40 E-05$ & 4. $40 \mathrm{E}-01$ \\
\hline$U-235$ & $2.68 E-02$ & $4.20 E+00$ & $4.20 E+04$ & $6.38 \varepsilon-07$ & $6.38 E-03$ \\
\hline $\mathrm{U}-238$ & $3.29 \varepsilon-01$ & $4.20 E+00$ & $4.20 E+04$ & $7.83 \mathrm{E}-06$ & $7.83 \mathrm{E}-02$ \\
\hline Pu-236* & $2.20 \mathrm{E}-04$ & $5.20 \mathrm{E}-01$ & $5.20 \mathrm{E}+03$ & $4.23 E-08$ & $4.23 \mathrm{E}-04$ \\
\hline$P u-238$ & $4.80 E+01$ & $6.20 \mathrm{E}-01$ & $6.20 E+03$ & $7.74 \mathrm{E}-03$ & $7.74 E+01$ \\
\hline Pu-239 & $1.10 E+02$ & $5.20 E-01$ & $5.20 \mathrm{E}+03$ & 2.12E-02 & 2. $12 E+02$ \\
\hline $\mathrm{Pu}-240^{\star}$ & $5.80 \mathrm{E}+01$ & 5.20E-01 & $5.20 \mathrm{E}+03$ & $1.12 E-02$ & $1.12 \mathrm{E}+02$ \\
\hline $\mathrm{Pu}-241$ & $4.40 E+03$ & $3.20 E+01$ & $3.20 \mathrm{E}+05$ & $1.38 E-02$ & $1.38 E+02$ \\
\hline $\mathrm{Pu}-242 *$ & $2.10 E+02$ & $5.20 \mathrm{E}-01$ & $5.20 E+03$ & $4.04 E-02$ & $4.04 E+02$ \\
\hline Am-241 & $9.30 \mathrm{E}+01$ & $5.20 E-01$ & $5.20 \mathrm{E}+03$ & $1.79 \mathrm{E}-02$ & $1.79 E+02$ \\
\hline \multirow[t]{2}{*}{$\mathrm{Cm}-244 *$} & $4.60 \mathrm{E}+00$ & $5.20 \mathrm{E}-01$ & $5.20 \mathrm{E}+03$ & $8.85 \mathrm{E}-04$ & $8.85 \mathrm{E}+00$ \\
\hline & & & Totals & $1.65 E-01$ & $1.65 E+03$ \\
\hline \multicolumn{4}{|c|}{ Metric tons to exceed Category 3 Threshold } & $6.07 E+00$ & $6.07 E-04$ \\
\hline \multicolumn{4}{|c|}{ KGS METAL FUEL TO EXCEED CATEGORY 3 THRESHOLD } & $6.07 E+03$ & $6.07 \mathrm{E}+00$ \\
\hline \multicolumn{4}{|c|}{ POUNDS METAL FUEL TO EXCEED CATEGORY 3 THRESHOLD } & $1.34 \mathrm{E}+04$ & $1.34 \mathrm{E}+00$ \\
\hline \multicolumn{4}{|c|}{ KGS OXIDE FUEL TO EXCEED CATEGORY 3 THRESHOLD } & $6.88 E+03$ & $6.88 E+00$ \\
\hline \multicolumn{4}{|c|}{ POUNDS OXIDE FUEL TO EXCEED CATECORY 3 THRESHOLD } & $1.52 E+03$ & $1.52 E+00$ \\
\hline \multicolumn{4}{|c|}{ NO. CANISTERS TO EXCEED CATEGORY 3 THRESHOLD } & $1.85 E+01$ & $1.85 E-03$ \\
\hline
\end{tabular}




$$
\begin{gathered}
\text { WHC-SD-SNF-HC-010Reru } 0 \\
\text { Page } 6 \text { of } 7
\end{gathered}
$$

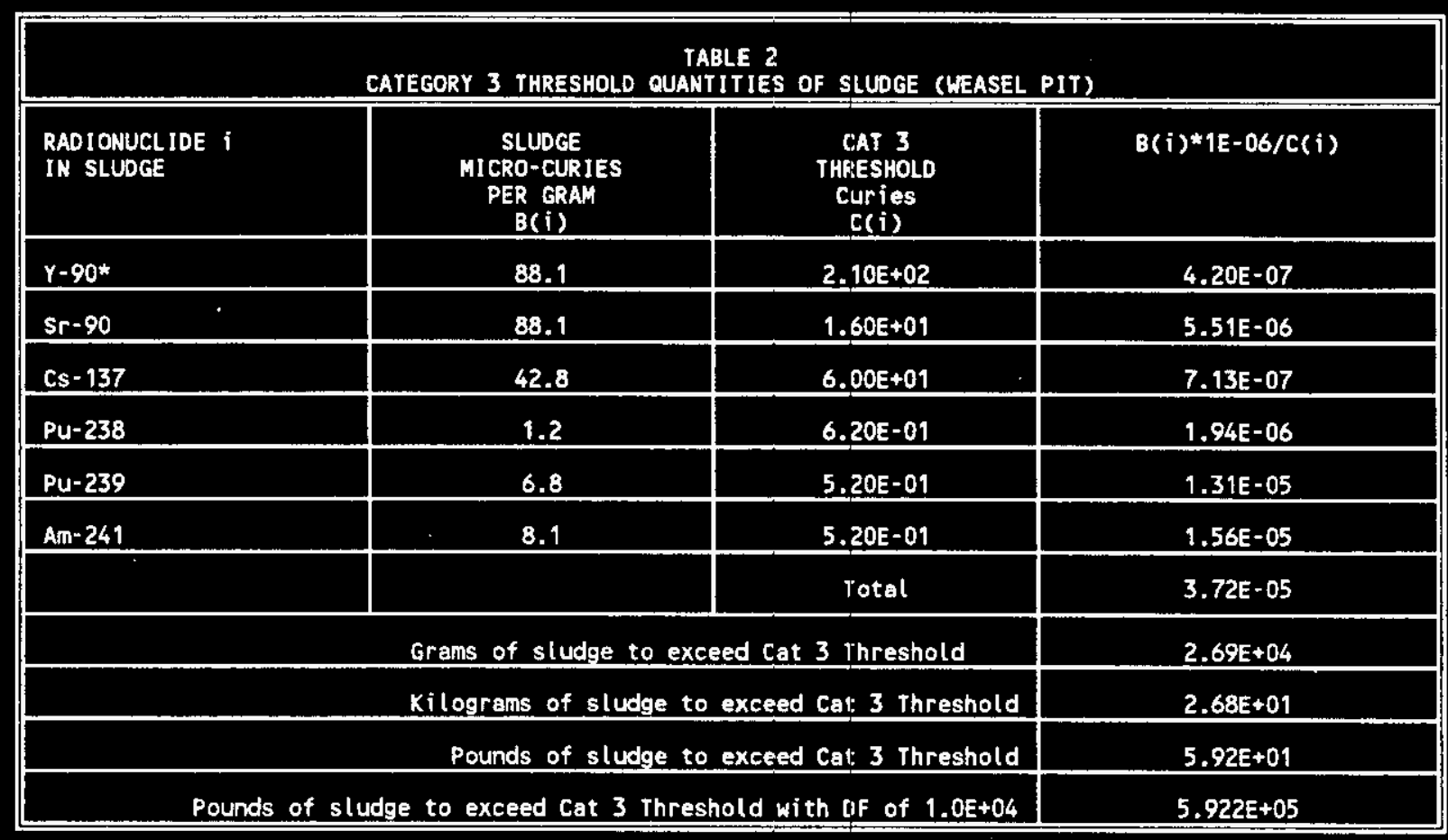

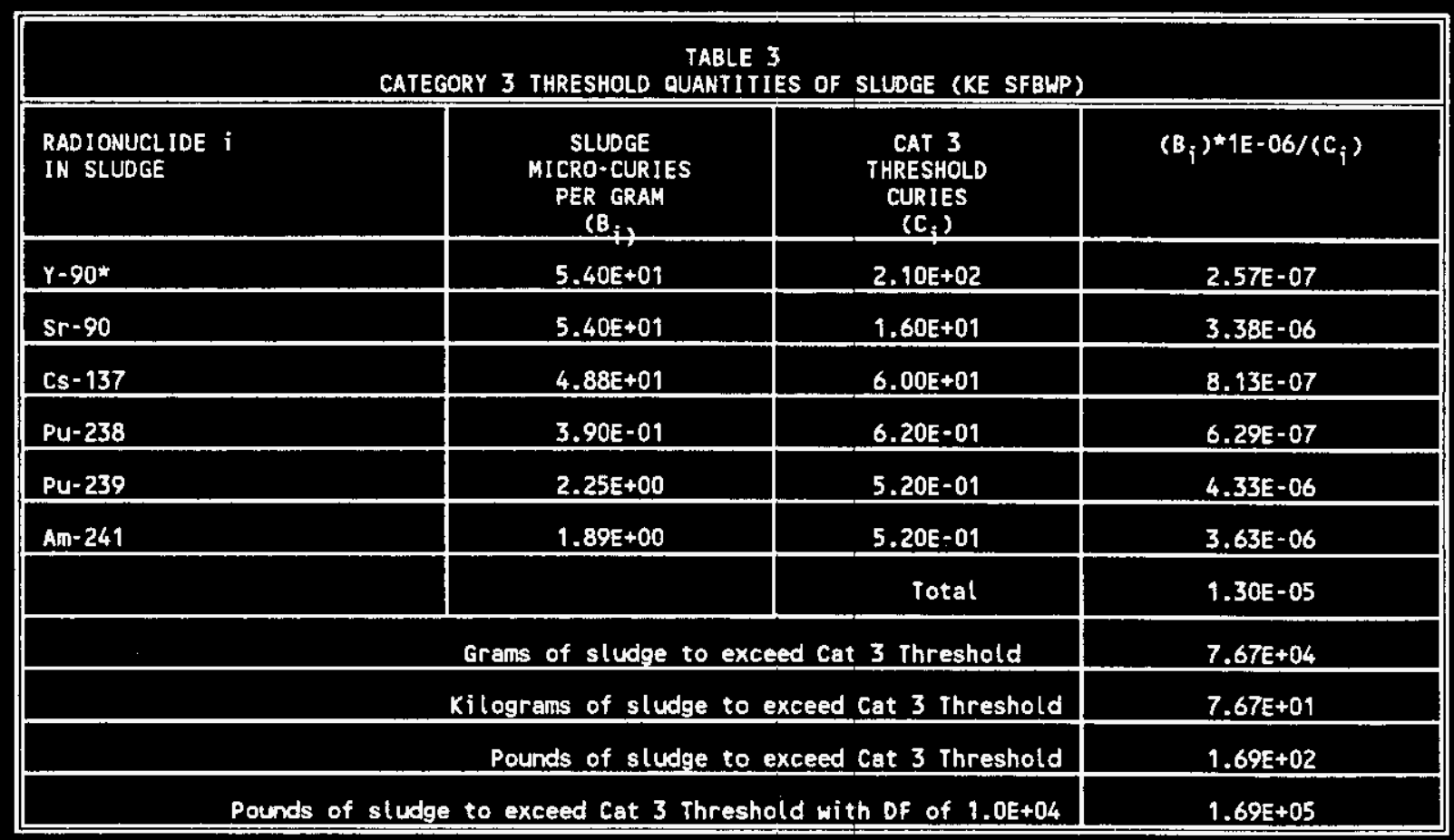


WHC-SD-SNF-HC-010Rero

Page 7 of 7

\begin{tabular}{|c|c|c|c|}
\hline & CATEGORY 3 THRESHOLD & $\begin{array}{l}\text { TABLE } 4 \\
\text { QUANTIIIES OF KE BASIN WATER }\end{array}$ & \\
\hline RADIONUCLIDE (i) & $\begin{array}{c}\text { UATER } \\
\text { MICRO-CURIES } \\
\text { PER LITER } \\
\text { B(i) }\end{array}$ & $\begin{array}{c}\text { CAT } 3 \\
\text { THRESHOLD } \\
\text { CURIES } \\
\text { C(i) }\end{array}$ & $B(i) * 1 E \cdot 06 / C(i)$ \\
\hline $\mathrm{H}-3$ & $3.40 \mathrm{E}+00$ & $1.00 E+03$ & $3.40 E-09$ \\
\hline$Y-90 *$ & $2.50 E+00$ & $2.10 E+02$ & $1.19 E-08$ \\
\hline Sr. 90 & $2.505+00$ & $1.60 E+01$ & $1.56 \mathrm{E}-07$ \\
\hline Cs-137 & $6.10 E+00$ & $6.00 E+01$ & $1.02 E-07$ \\
\hline Pu-238 & $6.90 E-02$ & $6.20 E-01$ & $1.11 \mathrm{E}-07$ \\
\hline Pu-239 & 3.30E-01 & $5.20 \mathrm{E}-01$ & $6.35 \mathrm{E}-07$ \\
\hline \multirow[t]{5}{*}{ Am-241 } & $7.00 E-03$ & $5.20 E \cdot 01$ & $1.35 E-08$ \\
\hline & & TOTALS & $1.03 \mathrm{E}-06$ \\
\hline & & CATEGORY 3 THRESHOLD LITERS & $9.68 E+05$ \\
\hline & & CATEGORY 3 THRESHOLD GALLONS & $2.56 \mathrm{E}+05$ \\
\hline & GPM FOR 24 HOURS & 0 REACH CATEGORY 3 THRESHOLD & $1.78 E+02$ \\
\hline
\end{tabular}

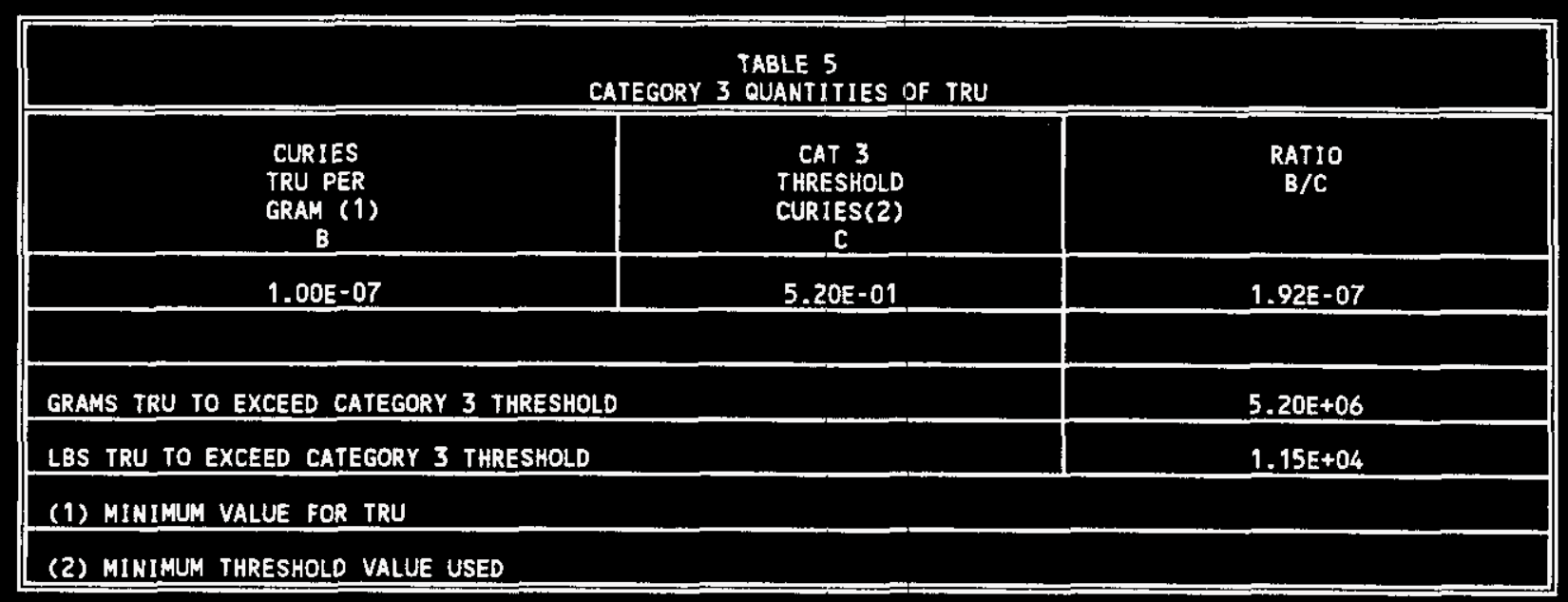




\section{DISTRIBUTION SHEET}

\begin{tabular}{|c|c|c|c|c|c|}
\hline \multirow{2}{*}{$\begin{array}{l}\text { To } \\
\text { Distribution }\end{array}$} & \multirow{2}{*}{\multicolumn{3}{|c|}{$\begin{array}{l}\text { From } \\
\text { Standards and Requirements }\end{array}$}} & \multicolumn{2}{|l|}{ Page 1 of 1} \\
\hline & & & & \multicolumn{2}{|c|}{ Date $01 / 25 / 96$} \\
\hline \multirow{2}{*}{\multicolumn{4}{|c|}{$\begin{array}{l}\text { Project Title/Work Order } \\
\text { WHC-SD-SNF-HC-010, Rev. 0, Hazard Categorization of 105-KE Basin } \\
\text { Debris Removal Project }\end{array}$}} & \multirow{2}{*}{\multicolumn{2}{|c|}{$\begin{array}{ll}\text { EDT No. } & 701976 \\
\text { ECN No. } & \text { N/A }\end{array}$}} \\
\hline & & & & & \\
\hline Name & MSIN & $\begin{array}{l}\text { Text } \\
\text { With All } \\
\text { Attach. }\end{array}$ & Text Only & $\begin{array}{l}\text { Attach.l } \\
\text { Appendix } \\
\text { Only }\end{array}$ & $\begin{array}{l}\text { EDT/ECN } \\
\text { Only }\end{array}$ \\
\hline $\begin{array}{l}\text { J. B. Crystal } \\
\text { C. DeFigh-Price } \\
\text { J. M. Escamillo (RL) } \\
\text { R. G. Gant } \\
\text { J. C. Hamrick } \\
\text { D. O. Hess } \\
\text { J. J. Jernberg } \\
\text { E. D. MacAlister (RL) } \\
\text { J. D. Mathews } \\
\text { R. H. Meichle } \\
\text { C. T. Miller } \\
\text { J. W. Osborne } \\
\text { J. P. Schmidt } \\
\text { J. S. Shuen (RL) } \\
\text { S. A. Slinn } \\
\text { M. J. Weimers } \\
\text { Central Files } \\
\text { SNF Project Files }\end{array}$ & $\begin{array}{l}X 3-85 \\
\times 3-79 \\
S 7-41 \\
X 3-79 \\
\times 3-71 \\
X 3-80 \\
X 3-85 \\
\text { S7-41 } \\
X 3-61 \\
X 3-79 \\
X 3-72 \\
X 3-80 \\
X 3-78 \\
\text { S7-41 } \\
X 3-74 \\
X 3-85 \\
\text { A3-88 } \\
\text { R3-11 }\end{array}$ & $\begin{array}{l}X \\
X \\
X \\
X \\
X \\
X \\
X \\
X \\
X \\
X \\
X \\
X \\
X \\
X \\
X \\
X \\
X \\
X\end{array}$ & & & . \\
\hline
\end{tabular}

* advanced ops made 